\title{
CNKSR1 wt Allele
}

National Cancer Institute

\section{Source}

National Cancer Institute. CNKSR1 wt Allele. NCI Thesaurus. Code C54408.

Human CNKSR1 wild-type allele is located in the vicinity of 1 p36.11 and is approximately $12 \mathrm{~kb}$ in length. This allele, which encodes connector enhancer of kinase suppressor of Ras 1 protein, is involved in receptor tyrosine kinase signaling attenuation. 